\title{
Employee Health and Safety Practices: An Exploratory and Comparative Study of the Shipping and Manufacturing Industries in Ghana
}

\author{
Samuel Howard Quartey ${ }^{1} \&$ Bill Buenar Puplampu ${ }^{1}$ \\ ${ }^{1}$ Central Business School, Central University College, Accra, Ghana \\ Correspondence: Samuel Howard Quartey, Department of Human Resource Management, Central Business \\ School, Central University College, P. O. Box DS 2310, Accra, Ghana. Tel: 233-243-167-387. E-mail: \\ squartey@central.edu.gh / shquartey@gmail.com
}

Received: August 20, 2012

Accepted: October 16, 2012 Online Published: November 15, 2012

doi:10.5539/ijbm.v7n23p81

URL: http://dx.doi.org/10.5539/ijbm.v7n23p81

\begin{abstract}
The state of employee health and safety in the shipping and the manufacturing industries in most developing economies remains largely unexamined. The purpose of this study was to examine employee health and safety practices in the shipping and manufacturing industries. The results from the quantitative analysis indicated that employees in the shipping and the manufacturing industries are prone to employee health and safety hazards. The findings suggest that management and employees demonstrated negative attitudes towards employee health and safety practices in the industries. Results also showed that the shipping industry had more employee health and safety initiatives than the manufacturing industry. The results further revealed that the age, gender and levels of education of employees do not influence employees' attitudes toward health and safety practices. The qualitative analysis also revealed that low productivity and high medical and insurance bills were associated with ineffective employee health and safety practices while effective health and safety practices led to high profitability and high productivity. Further, inadequate health and safety education and promotion as well as ineffective regulatory bodies were the major national challenges to health and safety practices. Moreover, non-compliance behaviours of employees as well as inadequate managerial support remained the industrial challenges to health and safety practices. In conclusion, industries must consider employee health and safety as their internal corporate social responsibility (CSR) investment.
\end{abstract}

Keywords: employee health and safety, corporate social responsibility, shipping, manufacturing, industries, Ghana

\section{Introduction}

The responsibility of every organization is to provide good working conditions and environment for employees devoid of risks, hazards, and diseases. Apart from the obvious ethical responsibility which gives rise to this position, there is also the view that there is a connection between the way a firm treats its employees and the way employees subsequently treat customers. This view is consistent with the cardinal assumption of the enlightened value maximization theory that improving employee wellbeing results in sustained long-term social relations and long term value for practicing firms. Today, employee health and safety as a corporate social responsibility (CSR) has received little attention. Perhaps, employers are usually interested in investing in equipment, machines, cars and factories to the neglect of the key "asset" of their organizations; the human resources. Although these investments are important, employee health and safety is vital if other investments are to yield greater results. Organizational growth, profitability and survival result in positive organisational citizenship behaviours which are determined by unquestionable health and safety practices.

Several studies have shown that, there is little or no attention to employee health and safety. These research findings suggest that millions of employees are victims of industrial accidents, hazards and diseases (Adebiyi and Owaba, 2009). Statistical findings indicate that, in the United State of America, there are about 6,500 fatalities and 9 million disabling injuries per a year (Roland and Moriarty, 1990). In the United Kingdom, 1.6 million injury accidents and 27 million non-injury accidents are recorded annually (Phelps, 1999). In Australia, the 2002 and 2004 figures suggest that fatalities were 2.6 per 100,000 employees while the injury rate was 2.7 per 1,000 
employees (NOHSC, 2004). In India, overall injury rate was 1.25 per 1,000 workers per year (Mohan et al., 2004), and 37 per cent of all reported accidents in Lebanon are industrial or work-related (Fayad et al., 2003). In the Latin America and Caribbean region, the number is as high as 13.5 per 100,000 workers. Also, it is 34 per 100,000 workers in the Republic of Korea and 140 per 1,000 of reported accidents in Iran (Roudsari and Ghodsi, 2005). In Finland, 20,016 hospitalizations for work-related injuries were recorded between 1990 and 1999 (Mattila et al., 2006). In France, 862,500 occupational accidents including 1,597 fatalities were recorded in the year 2000 (Fadier and Garza, 2006). The above statistics indicate that employees in both developed and developing countries are exposed to diverse and considerable risk of industrial accidents, hazards, diseases, and death. Indeed, it appears that many employers do not realize that protecting employees' health and safety is their corporate social responsibility (Montero et al., 2009).

However, with the increasing globalization and trade liberalization in most developing economies including Ghana, there is the need to put in place systems and structures that protect employees in every industry. Recently, employee health and safety issues in the country seem worrying, as employees complain about lack of effective policies, programmes, and practices that protect their well-being. Unfortunately, there is lack of adequate occupational health and safety infrastructures and database accounting system for industrial accidents, injuries and diseases (Ministry of Health Report, 2007). Besides these national challenges, most industries also fail in this regards. Most industries cannot boost of effective health and safety systems and structures. Consequently, employee health and safety may be compromised. Moreover, only few multinational mining firms have employee health and safety management systems in place to the neglect of the shipping and manufacturing industries (Li and Wonham, 1999). These occupational health and safety issues should raise questions of major concern for empirical research attention. Against this backdrop, this study attempted to investigate the prevailing state of employee health and safety practices and employee well-being in the shipping and manufacturing industries in Ghana.

\subsection{The Purpose of the Study}

Occupational health and safety in most developing economies have been under-studied. Besides, as far as the above human resource management issue is concerned, many studies have been conducted in different industry but not in the shipping and the manufacturing industries. Moreover, it is equally acceptable that, the manufacturing and the shipping industries constitute a major backbone of every economy, particularly in the Ghanaian economy. Further mainstreaming employee health and safety into corporate social responsibility frameworks remains largely unexamined in most developing countries, as many industries consider employee health and safety peripherally. This study sought to fill this void by exploring the state of employee health and safety practices in the shipping and the manufacturing industries in Ghana. As a result, this study sought to achieve the following research objectives:

- To assess whether the shipping industry has more effective employee health and safety initiatives than the manufacturing industry.

- To assess whether the manufacturing industry has more occupational health and safety hazards than the shipping industry.

- To understand whether employees in all the industries have positive attitudes toward employee health and safety practices than their management.

- To understand whether age, gender and levels of education of employees have any significant effect on employee health and safety attitudes.

- To identify the business and CSR case for employee health and safety initiatives in the shipping and manufacturing industries.

- To identify the industrial and national challenges to employee health and safety practices.

\subsection{Significance of the Study}

This study on employee health and safety practices in the shipping and manufacturing industries in Ghana is the first research work of its kind in Ghana. Hence, this study would breach the existing literature gap created by the dearth of work of such nature in Ghana. The findings from this study would practically help Human Resource practitioners and Occupational health Psychologists to develop employee health and safety programmes that are strategic and relevant. The study would also contribute to the existing literature in the field of Human resource management and Occupational health psychology, and provide insights into the state of employee health and safety practices in the industries and the country as a whole. The findings would help test the applicability of the theoretical basis of the study, as well as expand the boundaries of researches in Human resource management and Occupational health psychology. 


\section{Literature Review}

\subsection{Theoretical Background for Employee Health and Safety Practices}

Several theories provide theoretical backbone for understanding employee health and safety practices of buisness organsiations. One of the theories that explain why organizations should invest in employee health and safety practices is the enlightened value maximization by Jensen (2001). The basic position of enlightened value maximization theory is that an organization cannot maximize its long-term market value if it ignores or mistreats any important constituency. The theory argues that, organizations can maximize long term value by choosing among the competing demands of stakeholders or by making necessary trade-offs among the demands from stakeholders. Practically, shareholders want low risks and high returns, customers may also want low prices and high quality services. Employees may also want benefits, safer and healthier working environments, medical benefits and pension. Although it is important that the organisation's purpose of making profit should consider the social welfare of employees and the society as a whole, managements of organizations must focus on issues where there is a direct link to business needs (Grayson and Hodges, 2001). Therefore, being socially responsible includes making profit. Obviously, healthy employees can make huge profits; that is, by this theory, invest additional money in important constituency and that investment means greater financial returns to the organisation. Since the theory of enlightened value maximization leaves the decision for the organisations to decide which constituent is relevant and worth investing in, it is worth arguing that the health and safety of employees is paramount. According to this theory, there is a direct relationship or link between a firm's profitability, survival and growth and the management of its employees' health and safety.

\subsection{Definition of Occupational Health and Safety}

According to the International Labour Organization and World Health Organisation (1950s) occupational health and safety is protecting and maintaining the highest level of physical, mental and social well-being of workers in all occupations. It involves preventing ill-health caused by working conditions; protecting workers in their employment from risks resulting from factors adverse to their health; placing and maintaining workers in an occupational environment adapted to their physiological and psychological capabilities (Flin et al., 2000). In adapting employees' physiological and psychological capabilities to their works, Miller (1996) added that employee health and safety is the effect of work on employees and the effect of employees on their work. This places greater responsibility on organisations to help employees adapt to their work effectively in order to avoid risk of hazards, sickness and diseases at the workplace. Industrial work honestly poses a lot of health and safety challenges to employees, and employees depend on management for protection.

\subsection{Employee Health and Safety Practices in the Shipping and Manufacturing Industries}

The extant literature provides the basis for identifying most of the employee health and safety practices in organizations. Employee health and safety practices focus on activities such as identifying and managing employee health and safety hazards, improving health and safety attitudes, framing employee health and safety initiatives, and managing employee health and safety challenges in organizations. Several studies (e.g. Holtinen et al., 1995; Olaf et al., 2006; Hansen et al., 1994; Jensen et al., 2001) found that employees in the shipping industry are exposed to occupational health and safety hazards. These studies found occupational hazards such as oral and dental hazards, back pains; body pains, high temperatures, HIV infections, violence, slips and fall by seafarers. Besides, researchers such as Takeishi (2009), Swaen et al., (2009), Sallmen et al., (2008), and Lombardi et al., (2005) have also found occupational health and safety hazards such as noise-related operational hazards, chemical hazards, and eye injuries in the manufacturing industry. Further, few studies have also investigated employee health and safety attitudes in both industries and have found several attitudinal and behavioural tendencies of employees and managers toward employee health and safety practices. The findings at present are mixed with some studies finding positive atitudes and others finding negative attitudes towards employee health and safety practices. Generally, managers and supervisors seem to have positive attitudes towards health and safety practices than employees (Clarke, 2006; Law et al., 2006; Cheyne et al., 2002; Jong-Bae at al., 2008; Ma and Yuan, 2009; Pearson, 2008; and Perry, 2006).

Moreover, some recent studies have also found that there are several health and safety challenges in the shipping and the manufacturing industries, as employee health and safety practices are mostly neglected in the developing economies (Nuwayhid, 2004). In developing economies, one of the most common challenges to employee health and safety practices is lack of social and political will, as most developing countries lack the social and political mechanisms to translate scientific research findings into effective policies and national action plan for employees (Joyce, 1997, Levy (1996). Likewise, some studies have found that inadequate health and safety education and awareness (Regional Committee for Africa Report, 2004), weak health and safety infrastructures and inadequate 
occupational health and safety professionals (World Health Organization, 2005; Nicholson, 2004), inadequate health and safety procedures, pressure for production and non-compliance behaviours among employees (Jong-Bae et al., 2008), the capitalist economic system where firms consider profit making as their social responsibility (Buyisizwe, 1999) as well as ineffective governance structures and regulatory bodies to enforce health and safety policies (Koh, 1995). A sizable body of research has examined health and safety initaives in the shipping and the manufacturing industries. Despite the above health and safety problems, Shaw (2006) and Rolfe et al., (2006) identified preventative health and safety initiatives such as health and safety training, health and safety education and awareness creation for employees and management. Adebiyi and Charles-Owaba (2009) found that most manufacturing industries have instituted health and safety initiatives such as training, guarding, awareness, incentives, accidents investigation and the provision of personal protective equipment (PPE). Also, Cameron and Duff (2007) in their study disagreed with incentive giving as an initiative and concluded that the manufacturing industry can rather use health and safety goals and performance feedback without material rewards as an effective initiative. Some have also argued that a comprehensive health and safety promotion porgrammes have been identified as one of the most effective initiatives for managing employees' psychological and physiological problems in the manufacturing industry (Ott et al., 2009). They further argued that the manufacturing industry can combine medical examination, and health seminars to ensure positive health and safety management. A study by Wynn (2007) suggested that setting aggressive multi-year improvement goals for health and safety performance and holding business managers accountable for achieving progress and improvement in ergonomics can bring tremendous change in employee health and safety management practices. Further, Vassie and Lucas (2001), Li and Cullinane (2003), Canals et al., (2001), Thai and Grewal (2007), and Goodchild and Mohan (2008) investigating health and safety initiatives found that health and safety initiatives such as setting communication channels, measuring a company's health and safety objectives, ensuirng employee participation and empowerment and conducting risk assessment; medical assistance on board ships and coastal preventive services for maritime workers, clean truck programme, maritime risk management and maritime safety regulation, and safer and efficient maritime transportation have worked effectively for the shipping industry.

\subsection{Employee Health and Safety as a Case for Corporate Social Responsibility (CSR)}

One of the striking developments in the area of business during the past thirty years is the rise to prominence of corporate social responsibility (CSR). This continuing commitment by businesses to behave ethically and contribute to economic development while improving the quality of life of the workforce and their families as well as of the local community and the society at large (Business Council for Sustainable Development, 2005) provides a practical impetus that, every responsible business organization must be the one that goes beyond mere compliance with the law or meeting its fiduciary obligation to shareholders, or even doing good through philanthropy but recognizing that its day-to-day operations impact its internal stakeholders who are mostly employees. And it is in this impact where their responsibility lies (Andriof et al., 2002). The idea in health and safety is that work affects employees and employees' affect work. It is in this connection that a firm must consider employee health and safety as their social responsibility.

The connection between health and safety and corporate social responsibility is this: a sick, depressed and highly stressed employee cannot help maximize shareholder value and dividends. Employment and social policy that espouse social justice and emphasize legal and human rights of employees integrate corporate social responsibility principles. Besides legal issues, there are ethical issues as well. That is, CSR takes into account the interests of employees and their health and safety. Thus, employers should ensure that as part of their CSR they consider the health and safety of their employees; including work related stress, rigid working hours, work-life balance, poor human relations, and general employee well-being. Further, although there are methodological difficulties of accurately measuring costs and benefits, a study has shown that operating costs can be reduced by implementing effective health and safety programmes that reduce absenteeism and presenteeism which constitute some financial burden (BSR, 2005). Hopkins (2003) also argued that improved working conditions for employees can lead to improved productivity and total quality. Employee health and safety as a social responsibility attracts and retains quality employees, build a good reputation, increases shareholder value and reduces regulatory oversights (Tencati et al., 2004; Cowe et al., 2003; Swift and Zadek, 2002). 


\subsection{Business Case for Employee Health and Safety Practices}

Although there are methodological difficulties of accurately measuring costs and benefits of employee health and safety, few studies have provided some evidences to justify employee health and safety investment. For example, Miller and Haslam (2009) in their study found that most companies consider legal prosecution as the major drive for employee health and safety management. Fernandez-Muniz et al., (2009) argued that the need to gain competitive advantage and increase economic-financial returns must drive business firms to invest in employee health and safety practices. Ashraf and Naseem (2003) and EEF (2007) also found that poor employee health and safety practices leads to high absenteeism and lost workdays which eventually results in low productivity. Research has also linked high rate of employee turnover to poor employee health and safety practices (Rolfe et al., 2006). Likewise, business firms that invest in employee health and safety benefits reduced healthcare costs, workman compensation and insurance costs (Attridge, 2005; Loeppke et al., 2007; Wright and Marden, 2002). There is a positive relationship between total quality management practices and employee health and safey practices. For example, Mossink (2000) found that quality service provision has a strong connection with healthy employees. Smallman and John (2001) indicated that the fear of losing corporate credibility and reputation underpins corporate action for employee health and safety. Haefeli et al., (2005) argued that apart from the above benefits, firms maximize long term financial gains and improve their corporate performance when they invest in employee health and safety. CIPD (2007) confirmed the above findings by indicating that firms can effectively create shareholder value when some of the profits are re-invested in employees' health and safety management.

\subsection{Employee Health and Safety Practices and Demographic Characteristics}

Several researchers have studied the relationship between employee health and safety practices and demographic variables such as age, gender and level of education of employees. These findings merit consideration in this study. For example, a cross-sectional survey revealed that there is no difference in high scores for age, gender, education, seniority at work, or type of employment and health and safety attitudes of employees (Garcia et al., 2004). Another survey by Monazzam et al., (2009) also found that there is no significant effect on safety attitudes and worker's age, levels of education and work experience. Fang et al., (2006) conducted a survey to explore the relationship between safety climate elements and demographic characteristics and found significant relationships between personal characteristics such as gender, education level and individual health and safety attitudes. These findings are consistent with the findings of Hu et al., (1998) and Vinodkumar and Bhasi (2009) that demographic characteristics such as age, gender and levels of education have significant effect on health and safety attitude. In ascertaining the relationship between age and safety performance, Siu et al., (2003) observed that health and safety hazards and risk rate were not related to age in a curvilinear manner with injuries at first increasing with age and then decreasing with age. In this study, safety attitudes were also found to be related to age with older employee exhibiting more positive attitudes towards safety. These findings show that age has a significant effect on safety attitude but not on safety hazards. Although industries differ, this study explores the effect of demographic characteristics such as age, gender and levels of education on employee health and safety attitudes in the shipping and manufacturing industries.

\subsection{Research Hypotheses}

From the extensive review above, the following hypotheses were proposed to help achieve the research objectives:

Hypothesis 1: The shipping industry has more effective employee health and safety initiatives than the manufacturing industry.

Hypothesis 2: The manufacturing industry has more occupational health and safety hazards than the shipping industry.

Hypothesis 3: Employees in the shipping and manufacturing industries have positive attitudes toward employee health and safety practices than their managers.

Hypothesis 4: Age, gender and levels of education of employees have no significant effect on employee health and safety attitudes. 


\section{Methodology}

\subsection{Research Design and Method}

This study was an exploratory and comparative research design, using a hybrid of quantitative and qualitative research methodologies. Hybrid research methodologies are characterized by multiple data sources and carefully structured sample design. The target population consisted of employees from the shipping and the manufacturing industries. A total of 132 non-managers and managers were purposively selected. Data were gathered from two categories of respondents: the human resource and other line managers, and non-managerial employees. The qualitative data were collected from 12 managerial employees in a structured interview process, while the quantitative data were also collected from both managerial and non-managareial employees using questionniares. The questionnaire was the main data collection instrument, which consisted of open-and close-ended questions, adopted from Basen-Engquist et al., (1998) and Vinodkumar and Bhasi (2009) with a Cronbach's Alpha of 0.832. A five (5) Likert scale ranging from "strongly disagree (1) to strongly agree" (5) was used.

\subsection{Data Analysis Approaches}

The study collected quantitative and qualitative data. The quantitative data was analyzed using quantitative data analysis techniques. This was done with the help of Statistical Package for Social Sciences (SPSS, Version 16). The hypotheses were analyzed using two-way ANOVA and Independent t-test at 5\% level of significance. These quantitative methods were chosen to determine whether there was a significant difference between the shipping and the manufacturing industries on employee health and safety practices and issues. The qualitative data gathered from the structured interview was transcribed and analyzed using content and thematic analyses. Descriptive statistics, including frequency counts, percentages, cross tabulations and multiple responses were used to analyze, describe and interpret the data.

\subsection{Demographic Characteristics of Respondents}

The demographic data such as gender, age, job grade, level of education, type of industry/sector, type of organization, type of ownership, and tenure in the companies were analysed using cross tabulation. Out of the 132 respondents, the majority $(73.5 \%)$ were males and $26.5 \%$ females. The majority $(43 \%)$ of the respondents was between the ages of 18 and 29 years, and 38.6\% were between the ages of 30 and 44 years. A majority (50\%) of the respondents had between 1 and 5 years of work experience. About $50 \%$ of the respondents were first degree/HND holders while $8.3 \%$ of them were master's degree holders. A majority $(64.4 \%)$ of the respondents occupied non-management positions while $35.6 \%$ occupied management positions. A majority $(56.8 \%)$ of the respondents said they work in the private companies while $37.1 \%$ said they work in the multi-national companies. Further, $50 \%$ of the respondents worked in the manufacturing industry while the remaining $50 \%$ worked in the shipping industry.

\section{Results}

\subsection{Test of Hypotheses \& Objectives}

The hypotheses developed for the study were tested, and the research objectives designed to be achieved were also achieved. The first hypothesis posited that the shipping industry has more effective employee health and safety initiatives than the manufacturing industry. At $5 \%$ level of significance, $t_{(130)}=2.453, p<.05$ was observed. The results showed that there is a significant difference between the mean scores and the standard deviations for the shipping industry $(M=24.8333, S D=8.68346)$ and the manufacturing industry $(M=21.6970, S D=5.70282)$ on employee health and safety initiatives (see Table 1). Therefore the hypothesis that the shipping industry has more employee health and safety initiatives than the manufacturing industry was supported by the results of this study. 
Table 1. Independent t-test results-differences between the shipping and the manufacturing industries on employee health and safety initiatives

\begin{tabular}{cccccccc}
\hline Industry Type & $\mathbf{N}$ & Mean & Std. Deviation & Std. Error Mean & $\mathbf{d f}$ & $\mathbf{t}$ & $\mathbf{P}$ \\
\hline Shipping & 66 & 24.8333 & 8.68346 & 1.06886 & & & \\
Manufacturing & 66 & 21.6970 & 5.70282 & 0.70197 & & & \\
\hline
\end{tabular}

Source: field data 2010

Understanding the business and CSR drivers for employee health and safety initiatives in the shipping and manufacturing industries required an interview process which comprised 12 managerial employees from the manufacturing and the shipping industries. As a result, this study found that most managers associate costs and benefits analysis wih health and safety iniatives. The results from the qualitative analysis indicatd that a majority $(32.3 \%)$ of the managers believes that employee health and safety initiatives result in high profitability while $22.5 \%$ indicated that, high productivity is associated with effective employee health and safety practices through health and safety initiatives. A majority (30\%) of the managers also intimated that ineffective employee health and safety initiatives leads to low productivity with $26.7 \%$ indicating that ineffective employee health and safety initiatives also leads to increased or high medical costs associated with rampant injuries, illness and sickness among employees. According to the managers, these findings constitute the corporate social responsibility (CSR) drivers for the huge improvements in the employee health and safety iniatitives in the shipping industry (see Table 2).

Table 2. Coding framework: business \& CSR case for employee health and safety initiatives

\begin{tabular}{ccc}
\hline Managers Views (Costs) & Frequency & Percentages \\
\hline Low Productivity & 9 & 30.0 \\
High Medical Cost & 8 & 26.7 \\
low Profitability & 3 & 10.0 \\
High Absenteeism/Loss Time & 7 & 23.3 \\
Low Motivation \& High Turnover Rate & 1 & 3.3 \\
Increased Insurances Cost & 2 & 6.7 \\
Total & $\mathbf{3 0}$ & $\mathbf{1 0 0}$ \\
\hline Respondent Views (Benefits) & Frequency & Percentages \\
\hline High Productivity & 10 & 32.3 \\
High Profitability & 7 & 22.50 \\
High Motivation/Low Turnover Rate & 4 & 12.90 \\
Lower Medical Cost & 3 & 9.7 \\
Lower Absenteeism/Loss Time & 2 & 6.5 \\
Winning Contract & 5 & 16.1 \\
Total & 31 & 100 \\
\hline
\end{tabular}

Source: field data $2010,(\mathrm{n}=12)$ 
The second hypothesis intimated that the manufacturing industry has more occupational health and safety hazards than the shipping industry. At $5 \%$ level of significance, $\mathrm{t}_{(130)}=.245, \mathrm{p}>.05$ was observed. This indicated that there was no significant difference in mean scores and standard deviations between the shipping industry $(\mathrm{M}=39.1515$, $\mathrm{SD}=12.13671)$ and the manufacturing industry $(\mathrm{M}=38.6212, \mathrm{SD}=12.68085)$ on occupational health and safety hazards (see Table 3 ). These results suggest that both the shipping and the manufacturing industries are exposed to occupational health and safety hazards. Therefore, the hypothesis that the manufacturing industry has more occupational health and safety hazards than the shipping industry was not supported by the results of this study.

Table 3. Independent t-test results-differences between the manufacturing and the shipping industries on health and safety hazards

\begin{tabular}{cccccccc}
\hline Industry Type & $\mathbf{N}$ & Mean & Std. Deviation & Std. Error Mean & df & t & P \\
\hline Shipping & 66 & 39.1515 & 12.13671 & 1.49393 & & & \\
Manufacturing & 66 & 38.6212 & 12.68085 & 1.56085 & & & \\
\hline
\end{tabular}

Source: field data 2010

Understanding the widespread occupational health and safety hazards in the shipping and the manufacturing industries required an interview process to unearth the possible reasons. It was found that there is a connection between the increasing health and safety hazards and the industrial and national challenges to occupational health and safety practices as indicated by most managers. A majority $(61.1 \%)$ of the managers revealed that the most disturbing challenge to employee health and safety practices in their companies was the negative attitudes of employees and managers such as non-compliance behaviours by employees and lack of management's finanacial commitments and supports (see Table 4), while a majority (28.1\%) of the managers intimated that inadequate health and safety education, ineffective regulatory and institutional bodies as well as lack of comprehensive national health and safety policy and laws were some of the current challenges facing employee health and safey practices in the industries (see Table 5).

Table 4. Coding framework: industrial challenges facing employee health and safety practices

\begin{tabular}{ccc}
\hline Respondent Views & Frequency & Percentage \\
\hline Negative Attitudes of Employees & 6 & 33.3 \\
Negative Attitude of Management & 5 & 27.8 \\
Inadequate Health and Safety Experts to Hire & 1 & 5.5 \\
Low Health and Safety Culture in the Companies & 1 & 5.5 \\
Employee Health and Safety as Cost rather than Value & 1 & 5.5 \\
Lack of Quality Safety Equipment & 4 & 22.4 \\
Total & 18 & 100 \\
\hline
\end{tabular}

Source: field data 2010, $(\mathrm{n}=12)$ 
Table 5. Coding framework: national challenges facing employee health and safety practices

\begin{tabular}{ccc}
\hline Respondent Views & Frequency & Percentage \\
\hline Lack of clear National OHS Policy \& Laws & 5 & 15.6 \\
Negative Health and Safety Attitudes of Ghanaians & 5 & 15.6 \\
Inadequate Health and Safety Education & 9 & 28.1 \\
Inadequate health and safety researches \& Development & 1 & 3.1 \\
Lack of health and safety professionals & 3 & 9.5 \\
Ineffective Regulatory \& Institutional Bodies & 9 & 28.1 \\
Total & 32 & 100
\end{tabular}

Source: field data $2010,(n=12)$

The third hypothesis stated that employees in the shipping and manufacturing industries have positive attitudes toward employee health and safety practices than their managers. At $5 \%$ level of significance, $t_{(130)}=1.763, p>.05$ was observed. This result indicates that no significant difference in mean scores and standard deviations were observed between the employees $(\mathrm{M}=1.2985, \mathrm{SD}=15.48769)$ and their managers $(\mathrm{M}=1.2475, \mathrm{SD}=16.13404)$ on employee health and safety attitudes (see Table 6). Therefore, the hypothesis that employees in the shipping and manufacturing industries have positive attitudes toward health and safety practices than their managers was not supported by the results of this study.

Table 6. Independent t-test results-differences between employees and their managers on health and safety attitudes

\begin{tabular}{cccccccc}
\hline Job Grade & N & Mean & Std. Deviation & Std. Error Mean & df & t & P \\
\hline Managers & 47 & 1.2985 & 15.48769 & 2.25911 & & & \\
& & & & & 130 & 1.763 & $>.05$ \\
Employees & 85 & 1.2475 & 16.13404 & 1.74998 & & & \\
\hline
\end{tabular}

Source: field data 2010

The fourth hypothesis surmised that age, gender and levels of education of employees have no significant effect on health and safety attitudes. Result from the study showed that there is no significant main effects of gender $\left[\mathrm{F}_{(1,123)}\right.$ $=.125, \mathrm{p}>.05]$, age $\left[\mathrm{F}_{(3,123)}=1.159, \mathrm{p}>.05\right]$ and levels of education $\left[\mathrm{F}_{(4,123)}=.725, \mathrm{p}>.05\right]$ on health and safety attitudes (see Table 7). These results mean that age, gender and levels of education do not have effects on employees and managers attitudes towards health and safety practices. Therefore, the hypothesis that age, gender and levels of education of employees have no significant effect on health and safety attitudes was supported by the result from this study.

Table 7. Summary table of two-way ANOVA results-the main effect of gender, age and levels of education on health and safety attitudes

\begin{tabular}{cccccc}
\hline Source of Variance & Sum of Squares & Mean Square & F-ratio & df & P \\
\hline Gender & 32.505 & 32.505 & .125 & 1 & n.s \\
Age & 903.829 & 301.276 & 1.159 & 3 & n.s \\
Levels of Education & 754.024 & 188.506 & .725 & 4 & n.s \\
Error & 31961.208 & 259.847 & - & 123 & - \\
Total & 2148261.000 & - & - & 132 & - \\
\hline
\end{tabular}

Source: field data 2010 


\section{Discussion of Findings}

The objectives of the study were to assess whether the shipping industry has more effective employee health and safety initiatives than the manufacturing industry, to assess whether the manufacturing industry has more occupational health and safety hazards than the shipping industry, to understand whether employees in all the industries have positive attitudes toward employee health and safety practices than their management, to understand whether age, gender and levels of education of employees have any significant effect on employee health and safety attitudes, to identify the business and corporate social responsibility (CSR) case for employee health and safety initiatives in the shipping and manufacturing industries and to identify the industrial and national challenges facing employee health and safety practices.

One of the major findings of the study is that the shipping industry has more effective employee health and safety initiatives than the manufacturing industry. This finding confirms the statement by Canals et al., (2001); Thai and Grewal (2007); and Goodchild and Mohan (2008) that the shipping industry tend to have effective health and safety initiatives as a requirement for bidding contract from the oil and gas and the mining companies. The qualitative results further revealed that, these health and safety initiatives in the industries were underpinned by corporate social responsibility practices such as the need to maximize shareholder value and dividends and to increase employees productive capabilities which is also consistent with the findings of Mossink (2000); Zwetsloot and Pot (2004); Haefeli et al. (2005); Loeppke et al. (2007); and Homqvist et al. (2009). However, these benefits are possible when attempts are made to avoid costs associated with poor employee health and safety initiatives such as low productivity, high absenteeism and loss time, low employee motivation and increased medical and insurance costs (Ashraf and Naseem, 2003; Smallman and John, 2001; EEF, 2007; and Rolfe et al., 2006).

The findings of the study revealed that both the shipping and the manufacturing industries are exposed to occupational health and safety hazards. Consistent with the above finding were the findings of Jensen et al., (2001); Saarni et al., (2001); Olaf et al., (2006); and Hoever and Hansen (2005) who found occupational health and safety hazards in the shipping industry as well as Takeishi (2009); and Swaen et al. (2009) who also revealed same levels of health and safety hazards in the manufacturing industry. These findings confirm that both industries are exposed to occupational health and safety hazards. For example, the Crane operators in the shipping industry and the Machine operators in the manufacturing industry are all exposed to the same if not different sort of operational hazards. An attempt was made to understand why both the shipping and the manufacturing industries were facing increased occupational health and safety hazards. The qualitative results revealed that, while the industries cannot be difffernt from the country with regards to health and safety, both the industries and the country face several health and safety challenges such as negative attitudes of employees and management. This evidence supports the assertions of Ma and Yuan (2009); Miller and Haslam (2009); Wagenaar and Groeneweg (1987) that negative attitudes of managers and employees constitute a major challenge facing employee health and safety practices in the shipping and manufacturing industries.

Another major finding suggested that both employees and their managers have negative attitudes towards employee health and safety practices in their respective industries. This evidence also confirmed the third hypothesis and the numerous empirical findings such as those from (Clarke, 2006; Law et al., 2006; Cheyne et al., 2002; Jong-Bae at al., 2008; Ma and Yuan, 2009; Pearson, 2008; and Perry, 2006). On the other hand, the results indicated that, some of the national health and safety challenges include inadequate health and safety education, ineffective regulatory and institutional bodies and lack of comprehensive national health and safety policy and laws, with the labour laws requiring huge rectifications to suit modern employee health and safety standards. These national challenges identified by this study are consistent with those identified by the Ministry of Health Report (2007); Regional Committee for Africa Report (2004) and the WHO (2005).

Further, the finding from the study suggested that age, gender and levels of education do not appear to have any influence on employees' attitudes toward health and safety practices in their workplaces. This finding is consistent with the findings by Monazzam et al. (2009); and Garcia et al. (2004) who found that age, gender and levels of education do not have influence on health and safety attitudes. Surprisingly, this finding is inconsistent with the findings by Hu et al. (1998); Siu et al. (2003); Fang et al. (2006); and Vinodkumar and Bhasi (2009) who found that age, gender and levels of education influence employee health and safety attitudes. Empirically, it is expected that at least age and gender should influence health and safety attitudes in the workplace, as females and older employees should be more concerned about health and safety issues than males and young workers. This revelation should merits future research efforts in order to place the effect of age and gender on health and safety attitudes in a proper perspective. The above empirical findings confirmed the basic assumption and principle of the enlightened value maximization theory as postulated by Jensen (2001). The theory of enlightened value 
maximization was tested valid in this study. Therefore, it is the social obligation of every buisness organizations to invest in employee health and safety practices.

\section{Conclusion}

Employee health and safety practices as a case for social responsibility has been explored and certainly compared in the shipping and the manufacturing industries. The study has shown that the shipping industry seem and tend to be socially responsible for employee health and safety than the manufacturing industry. This is because the findings from this study revealed that the shipping industry have more employee health and safety initiatives than the manufacturing industry. The findings further revealed that both industries consider employee health and safety practices as their social responsibility initiative with the aim of benefiting from increased shareholder values, high producitivity, and increased corporate reputation and credibility. Most managers also attested to the fact that the need to cut costs associated with high employee turnover, high absenteeism, low employee motivation and increased medical and insurance bills underpin the employee's health and safety investments. However, in general, the corporate social responsibility of these industries towards employee health and safety practices has been mitigated by several industrial and national challenges. Amongst them was employee health and safety hazard. That is, the findings showed that employees in the shipping and the manufacturing industries are exposed to occupational health and safety hazards. Another major industrial and national health and safety challenge identified was the negative attitudes of employees and management towards health and safety practices. One of the empirical findings suggested that, employees and their managers can be blamed for poor health and safety practices because of their negative attitudes toward health and safety practices such as non-compliance behaviours of employees and lack of strong commitment and supports, especially, financial support from management. The study revealed other industrial and national health and safety challenges including inadequate health and safety education, ineffective regulatory and institutional bodies and lack of comprehensive national health and safety policy and laws, with the labour laws requiring huge rectifications for employee health and safety. All these challenges undermine the art of integrating employee health and safety into the corporate social responsibility frameworks of the industries.

Further, the study showed that employees' age, gender and level of education do not appear to have influence on health and safety attitudes at the workplace. By implication, whether one is male or female, older or younger, educated or uneducated, does not really guarantee positive attitudes to health and safety practices. In practice, it is expected that at least females and older workers would have positive attitudes toward employee health and safety practices, however, the findings from this study revealed otherwise. Despite the obvious limitation of generalizing this study in other industries, future research could examine the impact of age, gender and levels of education on employee health and safety attitudes. The findings of this study concludes that the shipping and manufacturing industries in Ghana have not fully mainstreamed employee health and safety practice into their corporate social responsibility (CSR) structures. Therefore, the conclusions drawn have some implications for management and policy makers. Management should consider employee health and safety as their social responsibility by taking into account the health and safety of employees in their business practices. Management should also invest in developing health and safety culture, organizing occupational health and safety training programmes, and promoting occupational health and safety. Nationally, it is also recommended that the country formulates and implements a comprehensive occupational health and safety national policy and laws backed by social and political will.The findings may not be described as a reflection of the general state of affairs in other industries in the country. The above results notwithstanding, offer useful policy implications that can be generalized in other industries such as the mining industries, construction industries, oil and gas industries.

\section{References}

Adebiyi, K. A., \& Charles-Owaba, O. E. (2009). Towards setting a sustainable manufacturing safety programme in Nigeria. Journal of Disease Prevention and Management, 18(4), 388-396. http://dx.doi.org/10.1108/09653560910984447

Anderson, J. C., \& Frankle, A. W. (1980). Voluntary social reporting: An ISO-beta portfolio analysis. The Accounting Review, 55(3), 467-479.

Andriof, J. S., Waddock, B. H., \& Rahman, S. (2002). Unfolding Stakeholder Thinking. Theory, Responsibility and Engagement. Sheffield: Greenleaf Publishing.

Ashraf, A. S., \& Naseem, M. S. (2003). Worker productivity and occupational health and safety issues in selected industries. Journal of Computers \& Industrial Engineering, 45, 563-572.

Attridge, M. (2005). The Business Cases for the Integration of Employee Assistance, Work - Life and Wellness 
Services. Journal of Workplace Behavioural Health, 20(1-2), 31-55. http://dx.doi.org/10.1300/J490v20n01_02

Basen-Engquist, K., Hudmon, K. S., Tripp, M., \& Chamberlian, R. (1998). Worksite health and safety climate: Scale development and effects of a health promotion intervention. Preventive Medicine, 27(1), 111-1119.

BSR (Business for Social responsibility). (2002). Overview of corporate social responsibility. Retrieved from http://www.bsrResources/IssuesBriefDetail.cfm?DocumentID =48809 (accessed 14th September, 2009)

Buyisizwe, S. L. D. (1999). Occupational hazards and diseases in manufacturing and processing industry in the Kingdom of Swaziland: Case study of Manzini district. National Social Welfare Training Institute (NSWTI). Department of Labour Studies, Dar es Salaam, Tanzania, 23-28.

Cameron, I., \& Duff, R. (2007). A critical review of safety initiatives using goal setting and feedback. Journal of Construction Management and Economics, 25(5), 495-508. http://dx.doi.org/10.1080/01446190701275173

Canals, M. L., Gomez, F., \& Harrador, J. (2001). Maritime health in Spain: Integrated services are the key. International Maritime Health, 52(1-4), 104-116.

Cheyne, A., Oliver, A., Tomás, J. M., \& Cox, S. (2002). The architecture of employee attitudes to safety in the manufacturing sector. Journal of Personnel Review, 31(6), 649-670. http://dx.doi.org/10.1348/096317902321119691

CIPD. (2007). Absence Management. CIPD, London.

Clarke, S. (2002). Safety climate in an automobile manufacturing plant: The effects of work environment, job communication and safety attitudes on accidents and unsafe behaviours. Personnel Review, 35(4), 413-430.

Cowe, R., \& Porritt, J. (2002). Government's Business-Enabling Corporate Sustainability. Forum for the Future, 3-7.

Drever, F. (1995). Occupational Health Decennial Supplement: Office of Population Censuses and Survey. Health and Safety Executive Series D5, 10.

EEF. (2007). Sickness Absence and Rehabilitation Survey. EEF, London.

Fang, D., Chen, Y., \& Wong, L. (2006). Safety Climate in Construction Industry: A Case Study of Hong Kong. Journal of Construction and Management, 132(6), 573-584. http://dx.doi.org/10.1061/(ASCE) 0733-9364(2006)132:6(573)

Fernandez-Muniz, B., Montes-Peon, J. M., \& Vazquez-Ordas, C. J. (2009). Relation between occupational health and safety management and firm performance. Safety Science, 47, 980-991.

Garcia, A. M., Boix, P., \& Canosa, C. (2004). Why do workers behave unsafely at work? Determinants of safe work practices in industrial workers. Journal of Occupational Environmental Medicine, 61, 239-246.

Goodchild, A., \& Mohan, K. (2008). Evaluation of Policy Impacts on Marine Terminal Operations. Journal of Maritime Economics \& Logistics, 10, 393-408. http://dx.doi.org/10.1057/mel.2008.13

Haefeli, K., Haslam, C., \& Haslsm, R. (2005). Perceptions of the cost implications of health and safety failures. Research Report, 403, HSE Books, Sudbury.

Hänninen, H. (2007). Negotiated Risks: The Estonia Accident and the Stream of Bow Visor Failures in the Baltic Ferry Traffic. (Unpublished Thesis) Helsinki school of economics, Helsinki.

Hansen, H. L., Brandt, L., Jensen, J., Balsley, U., Skarphedinsson, S., Jorgensen, A. F., David, K., \& Black, F. T. (1994). HIV infection among seafarers in Denmark. Scandinavian Journal of Infectious Diseases, 26(1), 27-31. http://dx.doi.org/10.3109/00365549409008587

Hill, D., Lucy, D., Tyers, C., \& James, L. (2007). What Works at Work. Review of Evidence Assessing the Effectiveness of Workplace Interventions to Prevent and Manage Common Health Problems. Corporate Document Services, Leeds.

Hoever, H. L., \& Hansen, H. L. (2005). Obesity among seafarers. Journal of International Maritime Health, 56(1-4), 48-55.

Holmqvist, M. (2009). Corporate social responsibility as corporate social control: The case of work-site health $\begin{array}{llll}\text { promotion. Scandinavian Journal of } & \text { Management, }\end{array}$ http://dx.doi.org/10.1016/j.scaman.2008.08.001

Holtinen, T., Saarni, H., Murtomaa, H., Pentti, J., \& Alvesalo, I. (1995). Seafaring: a risk for seaman's oral health. 
Acta Odontologica Scandinavica, 53(5), 275-278.

Hu, C. S., Lee, C. C., Shiao, C. J. S., \& Guo, L. Y. (1998). Employer's awareness and compliance with occupational health and safety regulations in Taiwan. Journal of Occupational Medicine, 48, 17-22. http://dx.doi.org/10.1093/occmed/48.1.17

International Labour Organization. (2004). Breaking Through the Glass Ceiling. Women in Management, International Labour Office. http://dx.doi.org/10.1111/j.1467-6486.2004.00438.x

Jensen, O. C., Laursen, F. V., \& Sorensen, F. L. (2001). International surveillance of seafarers' health and working environment: A pilot study of the method, and preliminary report. International Maritime Health, 52(1-4), 59-67.

Jensen, O. C., Sorensen, J. F., Kaerley, L., Canals, M. L., Nikolic, N., \& Saarni, H. (2004). Self-reported injuries among seafarers: Questionnaire validity and results from an international study. Journal of Accident Anal Prevention, 36(3), 403-413. http://dx.doi.org/10.1016/S0001-4575(03)00034-4

Jong-Bae, B., Sejong, B., Byung-Ho, H., \& Singh, K. P. (2008). Safety climate practice in Korean manufacturing industry. Journal of Hazardous Materials, 159, 49-52.

Joyce, S. (1997). Growing pains in South America. Environ Health Perspective, 105, 794-799. http://dx.doi.org/10.1289/ehp.97105794

Koh, D. (1995). Occupational health and safety promotion: problems and solutions. Safety Science, 20(2-3), 323-328. http://dx.doi.org/10.1016/0925-7535(95)00030-K

Lappalainen, J., \& Tapaninen, U. (2008). Maritime Personnel's Safety Attitudes. Centre for Maritime Studies Kotka unit. Mussalontie, 428, FI-48310, Kotka, Finland. Retrieved from hattp://www.merikotka.net

Law, W. K., Chan, A. H. S., \& Pun, K. F. (2006). Prioritizing the safety management elements: A hierarchical analysis for manufacturing Enterprises. Industrial Management and Data Systems, 106(6), 778-792.

Levy, B. S. (1996). Global occupational health issues: working in partnership to prevent illness and injury. Journal of American Association of Occupational Health Nurses, 44, 244-247.

Li, K. X. (2002). Maritime professional safety: prevention and legislation on personal injuries on board ships. IAME Panama 2002 Conference Proceedings.

Li, K. X., \& Cullinane, K. (2003). An Economic Approach to Maritime Risk Management and Safety Regulation. Journal of Maritime Economics and Logistics, 5, 268-284. http://dx.doi.org/10.1057/palgrave.mel.9100078

Li, K. X., \& Wonham, J. (1999). Who is safe and who is risk: 20-year-data analysis of different fleets. Maritime Policy and Management, 26, 137-144. http://dx.doi.org/10.1080/030888399286961

Loeppke, R., Taitel, M., Richling, D., Parry, T., Kessler, R. C., Hymel, P., \& Konicki, D. (2007). Health and productivity as a business strategy. Journal of Occupational and Environmental Medicine, 49, $712-721$. http://dx.doi.org/10.1097/JOM.0b013e318133a4be

Lokesh, K. (2002). Methodology of Educational Research. New Delhi: Vikas PUT AD.

Lombardi, D. A., Pannala, R., Sorock, G. S., Wellman, H., Courtney, T. K., Verma, S., \& Smith, G. S. (2005). Welding related occupational eye injuries: a narrative analysis. Journal of Injury Prevention, 11(3), 174-179. http://dx.doi.org/10.1136/ip.2004.007088

Ma, Q., \& Yuan, J. (2009). Exploratory study on safety climate in Chinese manufacturing enterprises. Safety Science, 47, 1043-1046. http://dx.doi.org/10.1016/j.ssci.2009.01.007

Macik-Frey, M., Quick, J. C., \& Nelson, D. L. (2007). Advances in Occupational health: From a stressful beginning to a positive Future. Journal of Management, 33(6), 812-816. http://dx.doi.org/10.1177/0149206307307634

McKinsey and Company. (2002). Investor opinion survey on corporate governance. London: McKinsey \& Company. http://dx.doi.org/10.1016/S0955-0674(02)00389-7

McWilliams, A., D., Siegel, S., \& Wright. M. P. (2006). Corporate Social Responsibility: Strategic Implications. Journal of Management Studies, 43(1), 1-18.

Meredith, T. (1986). Workers' health in Africa. Review of African Political Economy, 13(36), 24-29.

Miles, M. B., \& Huberman, M. A. (1994). Qualitative Data Analysis: An expanded Sourcebook (2 ${ }^{\text {nd }}$ Edition). California: Sage Publication. 
Miller, P., \& Haslam, C. (2009). Why employers spend money on employee health: Interviews with occupational health professionals from British Industry. Safety Science, 47, 163-169. http://dx.doi.org/10.1016/j.ssci.2008.04.001

Ministry of Health. (2007). National health policy: Creating wealth through health. Accra- Ghana.

Monazzam, M. R., \& Soltanzadeh, A. (2009). The Relationship between the Workers' Safety Attitude and the Registered Accidents. Journal of Research Health Sciences, 9(1), 17-20.

Montero, M. J., Araque, R. A., \& Rey, J. M. (2009). Occupational health and safety in the framework of corporate social responsibility. Journal of Safety Science, 46, 1-20. http://dx.doi.org/10.1016/j.ssci.2009.03.002

Mossink, J. C. M., \& Nelson, D. I. (2002). Understanding and Performing Economic Assessments at the Company Level. Protecting Workers' Health Series, 2, Geneva, World Health Organization. http://dx.doi.org/10.1016/S0968-8080(02)00085-X

Nicholson, P. J. (2004). Occupational health service in the United Kingdom: challenges and opportunities. Occupational Medicine. 54(3), 147-148. http://dx.doi.org/10.1093/occmed/kqg125

Nuwayhid, I. A. (2004). Occupational Health Research in Developing Countries: A Partner for Social Justice. American Journal of Public Health, 94(11), 1916-1921. http://dx.doi.org/10.2105/AJPH.94.11.1916

Olaf, C. J., Sorensen, F. L. J., Thomas, M., Canals, L. M., Nikolic, N., \& Hu, Y. (2006). Working condition in international seafaring. Journal of Occupational Medicine, 56(6), 393-397.

Ott, M. G., Oberlinner, C., Lang, S., Hoffmann, G., Nasterlack, M., Pluto, R. P., Trauth, B., \& Zober, A. (2009). Health and safety protection for chemical industry employees in a rotating shift system: programme design and acute injury and illness experience at work. Journal of Occupational Environmental Medicine, 51(2), 221-231. http://dx.doi.org/10.1097/JOM.0b013e318192bd0f

Pearson, G. (200). Making profits and sweet music: Business ethics. A European Review, 9(3), 191-199.

Pearson, K. (1999). Tolleys Survey of Senior Executives' Commitment to Health and Safety: 1999-2000. Croydon: Butterworths Tolley.

Perrow, C. (1999). Marine accidents and Normal accidents: Living with High Risk Technologies. Princeton, New Jersey: Princeton University Press.

Perry, T. (2006). The Business Value of Health: Linking CFOs to Health and Productivity. Integrated Benefits Institute, San Francisco, California.

Regional Committee for Africa Report. (2004). Occupational health and Safety in the African Region: Situational Analysis and perspectives. Fifty-fourth Session; WHO, Brazzaville, Republic of Congo, Africa.

Rolfe, H., Foreman, J., \& Tylee, A. (2006). Welfare or Farewell? Mental Health and Stress in the Workplace. National Institute of Economic and Social Research Discussion Paper, London.

Saarni, H., Laine, M., Niemi, L., \& Pentti, J. (2001). Health promotion in the Finnish shipping industry. Journal of International Maritime Health, 52(1-4), 44-58.

Sallmen, M., Neto, M., \& Mayan, O. N. (2008). Reduced fertility among shoe manufacturing workers. Journal of Occupational Environmental Medicine, 65(8), 518-524.

Shaw, T. (2006). Mental Health: The Last Workplace Taboo: Independent Research into What British Business Thinks. London: Future Foundation.

Siu, O., Phillips, O. R., \& Leung, T. (2003). Age difference in Safety attitudes and Safety performance in Hong Kong Construction Workers. Journal of Safety Science, 34(2), 199-205. http://dx.doi.org/10.1016/S0022-4375(02)00072-5

Smallman, C., \& John, G. (2001). British directors' perspectives on the impact of health and safety on corporate performance. Journal of Safety Science, 38, 227-239. http://dx.doi.org/10.1016/S0022-4375(01)00065-2

Swaen, G. M., Burns, C., Teta, J. M., Bodner, K., Keenam, D., \& Bodnar, C. M. (2009). Mortality study update of Ethylene Oxide workers in chemical manufacturing: a 15 year update. Journal of Occupational Environmental Medicine, 51(6), 714-723. http://dx.doi.org/10.1097/JOM.0b013e3181a2ca20

Swift, T., \& Zadek, S. (2002). Corporate Responsibility and Competitive Advantage of Nations. The Copenhagen Centre.

Takeishi, Y. (2009). Workplace health management and noise-induced hearing loss in Saitama Prefecture 
problems and corrective action. Nippon Jibiinkoka Gakkai Kaiho, 112(6), 480-486. http://dx.doi.org/10.3950/jibiinkoka.112.480

Tencati, A., Perrini, F., \& Pogutz, S. (2004). New Tools to Foster Corporate Socially Responsible Behaviour. Journal of Business Ethics, 53, 173-190. http://dx.doi.org/10.1023/B:BUSI.0000039407.37497.44

Thai, V. V., \& Grewal, D. (2007). The Maritime Security Management System: Perception of the International Shipping Community. Journal of Maritime Economics and Logistics, 9, 119-137. http://dx.doi.org/10.1057/palgrave.mel.9100175

United States Coast Guard (USCG). (2004). FY04 Annual OSH Report.

Vassie, H. L., \& Lucas, R. W. (2001). An assessment of health and safety management within working groups in the United Kingdom manufacturing sector. Journal of safety research, 32(4), 479-490. http://dx.doi.org/10.1057/palgrave.rm.8240097

Vinodkumar, M. N., \& Bhasi, M. (2009). Safety climates factors and its relationship with accidents and personal attributes in the chemical industry. Journal of Safety Science, 47, 659-667. http://dx.doi.org/10.1016/j.ssci.2008.09.004

Wagenaar, W. A., \& Groeneweg, J. (1987). Accidents at sea: Multiple causes and impossible consequences. International Journal of Man-Machine Studies, 27, 587-598. http://dx.doi.org/10.1016/S0020-7373(87)80017-2

World Health Organisation. (WHO). (2005). Regional strategy on occupational health and safety in SEAR Countries. Regional Office for South East Asia, New Delhi.

Wynn, M. L. (2007). Highlights of an industry benchmarking study: Health and safety excellence initiatives. Journal of Chemical Health and Safety, 15(3), 22-24.

Zwetsloot, G., \& Pot, F. (2004). Business Value of Health Management: Social Dimension of Organizational Excellence. Journal of Business Ethics, 55(2), 115-124. http://dx.doi.org/10.1007/s10551-004-1895-9 